\title{
Children as tour guides
}

\author{
Jordana Milne, University of Waterloo \\ Outi Rantala, University of Lapland, Multidimensional Tourism Institute (MTI) \\ Bryan S. R. Grimwood, University of Waterloo
}

\begin{abstract}
Despite recent calls to include children in tourism research, the trend of overlooking children's perspectives and experiences remains pervasive (Gram, O'Donohoe, Schänzel, Marchant, \& Kastarinen, 2019; Poria \& Timothy, 2014). This is a lost opportunity, especially in today's anthropocentric context, as children can offer insightful perspectives on human-nature relationships, and possible lessons for cultivating responsible human connections to, and co-existence with, non-human nature (Merewether, 2019). This research note emphasizes the importance of 'knowing with' children. Based on preliminary findings from a study that looked at nature-based proximity tourism and family nature walk experiences using sensory ethnographic methodologies, we show the value of considering children as tour guides. More specifically, we adopt a relational approach to engaging children's experiences in the world to illuminate under-explored and under-appreciated modes of knowing with non-human nature. Furthermore, we encourage future research that considers children not as a 'state of becoming' or as 'the future', but as influential actors within the present of tourism research (Carpenter, 2015; Leonard, 2019).
\end{abstract}

\section{Hearing children's voices in tourism studies}

The dated phrase "children must be seen and not heard" unfortunately still applies to much of the tourism literature today. Children's voices and experiences of tourism are often silenced, and the few studies that do include children in tourism look at knowing about them as opposed to knowing with them (Leonard, 2019; Poria \& Timothy, 2014). Studies that do include children often focus on the perspective of an adult, such as in family tourism experiences (Durko \& Petrick, 2013; Kennedy-Eden \& Gretzel, 2016; Lehto, Lin, Chen, \& Choi, 2012; Schänzel \& Yeoman, 2015), volunteer and orphanage tourism (Carpenter, 2015; Guiney, 2017), or adults recalling memories of tourist experiences as children (Omelan, Huk-Wieliczuk, \& Podstawski, 2015; Small, 2008). While many studies highlight the important role children play in family tourism decision-making (Canosa \& Graham, 2016; Wang, 2018; Wu, Wall, Zu, \& Ying, 2019), there is a tendency to not fully value children as the narrators of their own perspectives, stories, and experiences. Poria and Timothy (2014) discuss many challenges to doing tourism research with children, including: 
the required skill set and expertise to successfully conduct research involving children as participants; the strict ethical considerations when involving children in research; and the general lack of knowledge among tourism scholars in children behaviorial theories.

Learning about the stages of children's cognitive development and well-established bodies of knowledge, such as the sociology of childhood and children's studies, can help facilitate the inclusion of children in tourism (Canosa \& Graham, 2016; Poria \& Timothy, 2014). Indeed, a multi-disciplinary approach can help researchers understand the meanings and impacts of tourism experiences at different ages, as well as guide methodological decision-making (Canosa \& Graham, 2016). Nature-based tourism involving children, in particular, can also benefit from such a multi-disciplinary approach given its close association with areas such as nature-based education, children geographies, and leisure studies.

Specific concepts such as Gibson's (1979) 'affordance', and Gurholt and Sanderund's (2016) 'curious play' are examples from this broader literature that can inform nature-based tourism research with children. Gibson's concept of affordance refers to the possibilities and restrictions emerging from the environment, and it has been applied in studies examining children's nature relationships (see Laaksoharju \& Rappe, 2017; Niklasson \& Sandberg, 2010). Recently, affordances have been discussed as a relational approach to studying the context of children's outdoor recreation. Following Rautio (2013), relational approaches can work to acknowledge children as active beings, and highlight the dynamic, sensory interaction between children and their surroundings. The relational approach enables focus on the simultaneous emergence of the perceiver, the perception of the affordance, and the affordance itself (Ingold, 2000, p. 168; Rantala \& Puhakka, 2019).

Curious play is a theoretical framework that "gives primacy to the role of curiosity as a motivating factor for children's free play" (Gurholt \& Sanderund, 2016, p. 326). It emphasizes the ways that children can be motivated to learn with the non-human world exploring their physical limits and possibilities through their interactions with the physical and cultural landscape (Gurholt \& Sanderund, 2016). This theory highlights the ways that children's desire for knowledge about their realities drives the curious ways that they can potentially interact with the world. These are examples of concepts that tourism research can draw on for a multi-disciplinary understanding of the ways children interact with nature. Furthermore, these conceptualisations orient us towards interpreting how children co-create nature-play experiences with non-human materials. Specifically, they alert us to the sensory, embodied ways that children and their surroundings emerge in the interaction, which we illustrate below using empirical insights drawn from our study of nature-based proximity tourism and family nature walk experiences.

\section{Children-led walking tours}

Our discussion draws next on preliminary analyses of a sensory ethnographic study that explored nature-based proximity tourism experiences of families in Rovaniemi, Finland during the autumn of 2019. Proximity tourism is a mode of tourism that challenges people to reconceptualise the way they understand and experience tourism. Proximity tourism involves people 
adopting the tourist lens in spaces local to their primary place of residence; embracing a different point of view from the everyday, and approaching experiences with a sense of wonder and curiosity (Diaz-Soria, 2017; Jeuring \& Diaz-Soria, 2017; Jeuring \& Haartsen, 2017). Our study engaged proximity tourism as an approach to interacting with local nature environments, one that might enable enhanced environmental and financial sustainability in tourism. Proximity tourism eliminates the need for long distance air travel, which we know contributes much of carbon emissions associated with tourism (Boley, 2015; Eijgelaar, Nawijn, Barten, Okuhn, \& Dijkstra, 2016; Jeuring \& Haartsen, 2017). Proximity tourism also requires less financial and time commitment for families as they can return to their place of residence following their excursions or may potentially arrange accommodations near by, similar to a 'staycation' (Bloom, Nawijn, Geurts, Kinnunen, \& Korpela, 2016). Nature-based proximity tourism can help to enhance family's sense of place in local nature environments through direct interactions with these spaces. It can also encourage slower forms of travel, where families are invited to explore local nature with a sense of curiosity (Fuentes \& Svingstedt, 2018). Nature-based proximity tourism can be distinguished from other forms of nature-based recreation or outdoor education as participants deliberately choose to take on a tourist lens in proximate spaces (Diaz-Soria, 2017) through personal choice or facilitation by tour guides.

In the study, we used sensory ethnography to engage participating families in an exploration of local recreational areas and green space environments. According to Pink (2011), sensory ethnography represents a reorientation to ethnography vis-à-vis the senses. Specifically, Pink defines sensory ethnography as "an approach to doing ethnography that takes account of sensory experience, sensory perception, and sensory categories that we use when we talk about our experiences and our everyday life" (Pink, 2011, 00:25-00:55). Five English speaking families with children from the ages of two to seventeen were recruited for participation in the study using purposeful and snowball sampling (Table 1). Adult occupations consist of university professors, psychologists, muscicians, and tradesmen.

These families joined Jordana on separate occasions for a one to two hour nature walk experience that included a facilitated sensory scavenger hunt, free playtime, and semi-structured family focus groups following the walk. Jordana's plan was to guide families as they explored their chosen spaces during the walks and invite them to engage their senses in diverse and intentional ways. She attempted to do this by using a scavenger hunt that directed families to focus on finding things in nature using one or two senses at a time and a diverse array of materials (e.g., photography for sight; clay for creating texture stamps; or collecting berries for taste). Families were also observed during shared free time around a fire. This discussion draws on a preliminary reading of the data, focusing specifically on field notes taken during each walk and reflections written post walk. Data collection also consisted of photographs taken by Jordana and participants, audio recordings during each focus group, and video that was recorded during the sensory scavenger hunt using a GoPro camera. 
Table 1. Family demographics.

\begin{tabular}{|c|c|c|c|c|}
\hline FAMILY & NAME & $\begin{array}{l}\text { AGE } \\
\text { GROUP }\end{array}$ & $\begin{array}{l}\text { LOCATION OF } \\
\text { RESIDENCE }\end{array}$ & LOCATION OF WALK \\
\hline Family 1 & $\begin{array}{l}\text { Reko } \\
\text { Aina } \\
\text { Piia }\end{array}$ & $\begin{array}{l}41-50 \\
41-50 \\
7-8\end{array}$ & Rovaniemi, Finland & $\begin{array}{l}\text { Virikkolampi trail, } \\
\text { Rovaniemi }\end{array}$ \\
\hline Family 2 & $\begin{array}{l}\text { Danny } \\
\text { Aada } \\
\text { Lenny } \\
\text { Benny }\end{array}$ & $\begin{array}{l}31-40 \\
31-40 \\
2-3 \\
2-3\end{array}$ & Queensland, Australia* & $\begin{array}{l}\text { Ounasvaara hill, } \\
\text { Rovaniemi }\end{array}$ \\
\hline Family 3 & $\begin{array}{l}\text { Lilli } \\
\text { Adam } \\
\text { Henna } \\
\text { Nea }\end{array}$ & $\begin{array}{l}41-50 \\
31-40 \\
7-8 \\
7-8\end{array}$ & Rovaniemi, Finland & $\begin{array}{l}\text { Mortin männikkö, } \\
\text { Rovaniemi }\end{array}$ \\
\hline Family 4 & $\begin{array}{l}\text { Anna } \\
\text { Hannu } \\
\text { Saara } \\
\text { Tuula } \\
\text { Leevi }\end{array}$ & $\begin{array}{l}51-60 \\
40-50 \\
13-14 \\
14-15 \\
15-24\end{array}$ & Rovaniemi, Finland & $\begin{array}{l}\text { Virikkolampi trail, } \\
\text { Rovaniemi }\end{array}$ \\
\hline Family 5 & $\begin{array}{l}\text { Heidi } \\
\text { Venla } \\
\text { Veera }\end{array}$ & $\begin{array}{l}\text { Blank } \\
9-10 \\
13-14\end{array}$ & Rovaniemi, Finland & $\begin{array}{l}\text { Ounasvaara hill, } \\
\text { Rovaniemi }\end{array}$ \\
\hline
\end{tabular}

* Mom Aada is from Rovaniemi and finishing up higher education in Rovaniemi

As sensory walks commenced, however, we soon became aware of the certain tendencies of many children and how they encountered and engaged with the environment; many of the children were the ones guiding explorations and observations. Children led adults towards multiple important 'attractions' during the nature walks, stopping to guide them towards various unexpected ways of interacting with non-human materials. Children moved through the landscape often uninhibited by behavioral norms and expectations for moving through space in a linear, point A to point B, fashion prompting adults to do the same (Ingold, 2008). Children engaged in sensory exploration that relied less on visual. Moreover, they spent time within the in-between spaces, engaging in multi-species imaginative play. Because of these initial observations, we began to identify children as the tour guides of the nature-based proximity tourism activities we were investigating. Children as tour guides not only seemed complementary to how families experience familiar places with curiosity and wonder, but it also revealed how children facilitate knowing with non-human nature. By weaving non-human nature into the stories of their lives, many children brought awareness to "the diversity of ways in which we are nature already" (Rautio, 2013, p. 394). We next present four vignettes that we call 'stops' on the child led guided tour, based on a preliminary arrangement and analytical reading of the data. These stops combine the experiences of the five separate nature walks into one 'tour' to help illustrate the ways in which we learned with children. 


\section{Stop 1: Rock \& berry island}

The first 'stop' on the tour involved the children guiding Jordana and families towards a different way of moving through the hills and forests. Within minutes of the first walk, eight-yearold Piia instructed mom, dad, and Jordana to hop from rock to rock or root and to see who could go the longest without stepping on the dirt path. During the second walk, two-year-old Benny and three-year-old Lenny led Jordana and parents on a berry-focused tour, guiding the group towards a stop/start rhythm as they looked for berries to eat, getting up close to the forest floor away from the trail. The forest inspired children's curiosity and provided opportunities for exploratory experiences through the many loose parts and sensory stimuli afforded to them (Zamani, 2016). Children moved on and off trails, they crawled and climbed on top of rocks, hid behind trees, and moved through the forest in playful and curious way (Beery \& Jørgensen, 2018; Waite, 2010).

Children encouraged adults to move with them in these ways, and this way helped to break through expectations of how an adult is typically expected to take part in a nature walk or hike. Through various ways (i.e., signage, trail maintenance) people's interaction and movement through nature is regulated by park managers, creating affordances, guiding people towards certain paths, and encouraging or discouraging certain behavior (Lekies \& Whitworth, 2011). Hannam and Witte (2018) highlight how walking often has physical, cultural, or political restrictions, with social expectations on how walking, or hiking, should be performed. An adult may face strange looks or glances from fellow hikers for hiding under a tree or using a log as a balance beam, but these behavioral expectations are lessened when perceived as taking care of or playing with children. Rautio (2013), referencing Bennett (2010), states that in order to relate to our material surroundings in new ways, a little foolishness or silliness can go a long way; "a genuinely new way of thinking necessarily appears nonsense for it presents a break from the common sense, the norm" (Rautio, 2013, p. 401). We propose that it is precisely this break from the norm that can help move tourism towards a new conceptualization of human-nature relationships.

\section{Stop 2: Lapland's famous puffy mushroom}

Whether it was two-year-old Benny putting her nose directly on rocks, pinecones, and leaves, or seven-year-old Henna giggling as she poked a mushroom that puffed out dust, the children in the study were constantly guiding the group towards sensory exploration and play. This is consistent with much of the literature on the ways children interact with nature (Beery, 2013; Beery \& Jørgensen, 2018). Children explore up close within nature and are more sensuous, with their reliance on vision less dominant than adults (Bartos, 2013). Children had the opportunity to develop a sense of place through these sensuous, embodied interactions with the landscapes and it allowed them to learn about biodiversity and conservation. Sensory interaction led to discussions about what berries or mushrooms are edible, respectful behavior eating around a fire, and the importance of carrying out all garbage (Beery, 2013; Beery \& Jørgensen, 2018). As adults rely heavily on visual cues in nature to experience wonder or delight, other senses often become supplementary or in addition to the visual (Allen-Collinson \& Leledaki, 2015). In our walks the 
embodied experiences of the children enrolled the whole family into encountering nature in sensory ways.

During family three's walk, mom and thirteen year old Veera often stayed on the trail and pointed at things they saw, or verbalized elements they were drawn to during the walk. It was ten year old Venla and Jordana that would veer off the trail to touch, smell, or take photos of these items, while Veera and mom had a tendency to watch from the trail. Veera had to leave the walk early, but towards the end of the walk mom chose to join Venla as she began her rock smashing routine. The rocky trail afforded Venla the opportunity to break rocks against each other revealing the geological patterns within. Although concerned for the groups safety and flying shards of rock, mom Heidi joined Venla in examining the patterns, sparkle, and texture swirling around the inside of the rocks. Many children in the study led adults closely towards the forest floor, the bark of trees, and the center of rocks, exploring with senses other than sight.

\section{Stop 3: The in-between spaces}

What constitutes an 'attraction' or a destination may be very different for children and adults. In Finland, many trails have a 'laavu', a wooden shelter with a fireplace and wood that is maintained by the city. During our hikes, these shelters served as many of the destinations for the adults, but children often had different plans. Benny and Lenny would have stayed playing on the little boulders all day if dad had not pulled them off, and Venla was much more interested in smashing rocks to reveal the patterns within than she was with getting back home. Children encouraged families to focus less on getting to a specific lookout or destination and to explore the nature spaces in between.

Graham (2017) discusses the importance of wandering as a way of encountering the spaces in-between departure point and destination. Drawing on Ingold's (2011) concept of wayfaring, Graham illuminates how movement is much more fundamental to human life than is the reaching of an end point. It is between a departure point and an end point or along lines of movement where an individual's lifeworld is established (Graham, 2017). This conceptualization echoes how many of the children's wandering between adult planned end points in this study influenced the adults to move through nature as opposed to across it, building relationships across the meshwork of human and non-human actors (Graham, 2017; Ingold, 2011). The children often persuaded parents against their will to abandon timelines, forget about being cold, or to play in and explore nature spaces. They influenced Jordana and the families to worry less about getting to the final fire pit or lookout point, and to explore things in the proximal environment such as a boulder or a berry, that may have been ignored without children's presence.

\section{Stop 4: Restaurant a la rock}

During Piia's tour with her family, she made sure that everyone on the tour got fed, humans and non-humans alike. When Piia's mother asked for her 'cookers tax' or a piece of the freshly made bannock she had just handed her daughter, Piia graciously shared her treat. Piia also made sure to give a piece to the rocks around the firepit because 'they helped cook too.' This interaction 
highlights children's animism, which Merewether (2019) defines as the common worlding between mutually entangled humans and non-humans. Common worlding eliminates the division between children and nature and emphasizes the agency humans and non-humans have on each other. The rocks in this example house the fire, preventing the fire from spreading, and insulating the fire's heat. The rock helps to facilitate the cooking experience and, through its interaction with Piia and her mother, influences how much bannock Piia will eat.

This animism can often be perceived as naiive or problematized and educated out of children, but scholars are beginning to highlight the importance of this view in recognizing the agency of non-human nature and materials (Merewether, 2019; Rautio, 2013). In these anthropocentric times, many scholars are turning to post-humanist theory and new materialisms to emphasize the ways in which humans and non-humans are mutually entangled (Barad, 2007; Merewether, 2019; Rautio, 2013; Änggård, 2016). Children's animism and common worlding between humans and non-humans can move adults closer to accepting and recognizing non-human agencies and, in turn, move us away from hierarchical worldviews where humans reign supreme as the only agential beings.

\section{Children teach adults...}

The children in this study often led adults towards knowing with them, and knowing with nature. They led us towards moving through nature in curious, exploratory ways, using all our senses and illuminating the ways humans and non-humans are mutually entangled. They guided us in wayfaring, and showed how we can see familiar spaces in new ways if we choose to see things with a sense of wonder and awe. Gurholt and Sanderud (2016) propose "that children should be viewed existentially, as active explorers and playful agents in shaping their selves, knowledge, skills and world-view" (p. 326). This research note has illustrated that children are indeed active in shaping their world-views, but also that knowing with children in nature-based proximity tourism settings can influence adults worldviews as well.

This attitude towards enjoying the journey and exploring with the senses can also highlight other sustainable types of tourism like slow travel, a form of tourism that rejects transportation by air, and emphasizes enjoying the journey instead of reaching a destination (Fuentes \& Svingstedt, 2018). Spending time with children in local nature spaces not only guides parents towards an understanding of nature-based proximity tourism and tourism as a chosen experience (Diaz-Soria, 2017), but it also emphasizes this overlapping concept of slow travel. Fuentes and Svingstedt (2018) state "what is important here is taking one's time, escaping the hectic life, adopting another pace, and connecting with local culture" (Fuentes \& Svingstedt, 2018, p. 15). Children lead families to become wayfarers, enjoy the journey, slow down, and connect with the in-between spaces.

Although learning from children presents a great opportunity in tourism and nature-based tourism research, it is important to mention some of the limitations of this study. Different children have different relationships with nature, and many face barriers to building this relationship. These relationships also change as children develop across the lifespan. It is important 
to acknowledge that not all children have the same relationship with nature as it can take time and sustained interaction to become comfortable to engage in curious play outdoors (Gross, Mcgee, James, \& Hodge, 2019; Gurholt \& Sanderud, 2016). Decreased access to green spaces and more organized, overscheduled lives are a few of the many barriers children face to spending time with nature (Mjaavatn, 2016; Skar, Gundersen, \& O'Brien, 2016). Not investing in this relationship can lead to fear, disgust, and a desire for more modern comforts as children move into adolescence (Gross et al., 2019). In the context of our study, things like weather, hunger, fatigue, and irritability were all also challenges that affected the children - especially the younger ones - and families at different points during the walks, influencing the children's ability to focus on the scavenger hunt or interview questions.

We also must consider how children's relationships with nature will change across the lifespan often moving towards an interest in more structured, organized leisure activities in adolescence (Nordbakke, 2019). A few of the older children in the study looked for and desired more organized activities and challenges, occasionally losing interest and turning to technology to keep themselves entertained. Thirteen year old Veera was one of these children, who tended to stay on the trail and relied on her sense of vision to interact with her surroundings. This further highlights the importance of a multi-disciplinary understanding of children's development; how their relationship with nature changes over time and how these changes influence their relationships with tourism. Future tourism research should focus on children's changing relationships with nature through adolescence to better understand how their role as a tour guide will transform over time. In spite of these limitations, this study highlights the potential of learning with children at every stage of development, and demonstrates the agency of children in guiding the rest of us towards different ways of building intimate relationships with nature.

Children are not just the future, they are also the present. Linzmayer and Halpenny (2014) state that "children in most societies are valued for their potential and for what they will grow up to be but are devalued in terms of their present perspectives and experiences" (p. 414). In this research note, our aim has been to demonstrate that we do not need to wait for children to become adults before we can learn with them. In today's turbulent political and climatic circumstances, children and youth around the world are taking action and speaking out for their future. Greta Thunberg and Autumn Peltier are advocating for climate justice and clean water, Florida Parkland school shooting survivors organized The March for Our Lives, and many Indigenous youth are protesting the Dakota Access Pipelines. All of these children demonstrate their deeply rooted and passionate connection to environmental and social justice. We learn with children all the time, and we should appreciate these learning experiences in tourism and nature-based tourism studies. The research note has provided insight into what children can teach us about environmental connection and sustainable attitudes. Perhaps we need to learn to be more attentive listeners and observers of children and enable them to be present-day proximity tour guides. 


\section{Acknowledgements}

The study was funded by the Mitacs Globalink Research Award (grant number IT14772) and Academy of Finland (grant number 324493).

\section{References}

Allen-Collinson, J. , \& Leledaki, A. (2015). Sensing the outdoors: A visual and haptic phenomenology of outdoor exercise embodiment. Leisure Studies, 34, 457-470. https://doi.org/10.1080/02614 367.2014 .923499

Barad, K. M. (2007). Meeting the universe halfway: Quantum physics and the entanglement of matter and meaning. Durham, NC: Duke University Press.

Bartos, A. E. (2013). Children sensing place. Emotion, Space and Society, 9, 89-98. https://doi. org/10.1016/j.emospa.2013.02.008

Beery, T. H. (2013). Nordic in nature: Friluftsliv and environmental connectedness. Environmental Education Research,19(1), 94-117. https://doi.org/10.1080/13504622.2012.688799

Beery, T. \& Jørgensen, K. A. (2018). Children in nature: Sensory engagement and the experience of biodiversity. Environmental Education Research, 24(1), 13-25. https://doi.org/10.1080/13504622 .2016 .1250149

Bennett, J. (2010). Vibrant matter: A political ecology of things. Durham, NC: Duke University Press.

Bloom, J. D., Nawijn, J., Geurts, S., Kinnunen, U., \& Korpela, K. (2016). Holiday travel, staycations, and subjective well-being. Journal of Sustainable Tourism, 25, 573-588. https://doi.org/10.1 080/09669582.2016.1229323

Boley, B. B. (2015). To travel or not to travel? Both have implications for sustainable tourism. Tourism Planning \& Development, 12, 208-224. https://doi.org/10.1080/21568316.2014.925489

Canosa, A. , \& Graham, A. (2016). Ethical tourism research involving children. Annals of Tourism Research, 61, 219-221. doi: http://doi.org/10.1016/j.annals.2016.07.006

Carpenter, K. (2015). Childhood studies and orphanage tourism in Cambodia. Annals of Tourism Research, 55, 15-27. https://doi.org/10.1016/j.annals.2015.08.010

Diaz-Soria, I. (2017). Being a tourist as a chosen experience in a proximity destination. Tourism Geographies, 19, 96-117. https://doi.org/10.1080/14616688.2016.1214976

Durko, A. M., \& Petrick, J. F. (2013). Family and relationship benefits of travel experiences: A literature review. Journal of Travel Research, 52, 720-730. https://doi.org/10.1177/0047287513496478

Eijgelaar, E., Nawijn, J., Barten, C., Okuhn, L., \& Dijkstra, L. (2016). Consumer attitudes and preferences on holiday carbon footprint information in the Netherlands. Journal of Sustainable Tourism, 24, 398-411. https://doi.org/10.1080/09669582.2015.1101129

Fuentes, C., \& Svingstedt, A. (2018). The practice of slow travel: Understanding practitioners' recruitment, career and defection. In Theories of Practice in Tourism (pp. 10-28 ). London: Routledge.

Gibson, J. J. (1979). The ecological approach to visual perception. Boston, MA: Houghton Mifflin. 
Graham, M. E. (2017). From wandering to wayfaring: Reconsidering movement in people with dementia in long-term care. Dementia, 16, 732-749. https://doi.org/10.1177/1471301215614572

Gram, M., O’Donohoe, S., Schänzel, H., Marchant, C., \& Kastarinen, A. (2019). Fun time, finite time: Temporal and emotional dimensions of grandtravel experiences. Annals of Tourism Research, 79. https://doi.org/10.1016/j.annals.2019.102769

Gross, L., Mcgee, J., James, J. \& \& Hodge, C. (2019). From play to pedagogy: Formative childhood experiences and the development of preservice elementary science educators. Journal of Science Teacher Education, 30, 856-871. https://doi.org/10.1080/1046560x.2019.1616516

Guiney, T. (2017). "Hug-an-orphan vacations": "Love” and emotion in orphanage tourism. The Geographical Journal, 184, 125-137. https://doi.org/10.1111/geoj.12218

Gurholt, K. P., \& Sanderud, J. R. (2016). Curious play: Children's exploration of nature. Journal of Adventure Education and Outdoor Learning, 16, 318-329. https://doi.org/10.1080/14729679.2016.11 62183

Hannam, K., \& Witte A. (2018). Theorising practices of walking in tourism. In Theories of Practice in Tourism (pp. 29-40). London: Routledge.

Ingold, T. (2000). The perception of the environment: Essays on livelihood, dwelling and skill. London: Routledge.

Ingold, T. (2008). Bindings against boundaries: Entanglements of life in an open world. Environment and Planning A: Economy and Space, 40, 1796-1810. https://doi.org/10.1068/a40156

Ingold, T. (2011). Being alive: Essays on movement, knowledge and description. New York, NY: Routledge.

Jeuring, J., \& Diaz-Soria, I. (2017). Introduction: Proximity and intraregional aspects of tourism. Tourism Geographies, 19, 4-8. https://doi.org/10.1080/14616688.2016.1233290

Jeuring, J., \& Haartsen, T. (2017). The challenge of proximity: The (un)attractiveness of near-home tourism destinations. Tourism Geographies, 19, 118-141. https://doi.org/10.1080/14616688.2016.1 175024

Kennedy-Eden, H., \& Gretzel, U. (2016). Modern vacations - modern families: New meanings and structures of family vacations. Annals of Leisure Research, 19, 461-478. https://doi.org/10.108 o/11745398.2016.1178152

Laaksoharju, T., \& Rappe, E. (2017). Trees as affordances for connectedness to place - A framework to facilitate children's relationship with nature. Urban Forestry \&Urban Greening, 28, 150-159. https://doi.org/10.1016/j.ufug.2017.10.004

Lehto, X. Y., Lin, Y., Chen, Y., \& Choi, S. (2012). Family vacation activities and family cohesion. Journal of Travel \& Tourism Marketing, 29, 835-850. https://doi.org/10.1080/10548408.2012.730950

Lekies, K. S., \& Whitworth, B. (2011). Constructing the nature experience: A semiotic examination of signs on the trail. The American Sociologist, 42, 249-260. https://doi.org/10.1007/s12108-0119129-y

Leonard, M. (2019). The teenage gaze: Teens and tourism in Belfast. Childhood, 26, 448-461. https://doi.org/10.1177/0907568219843326 
Linzmayer, C. D. , \& Halpenny, E. A. (2014). 'I might know when Im an adult': Making sense of children's relationships with nature. Children's Geographies, 12, 412-428. https://doi.org/10.1080 /14733285.2013.821262

Merewether, J. (2019). New materialisms and children's outdoor environments: murmurative diffractions. Children's Geographies, 17, 105-117. https://doi.org/10.1080/14733285.2018.1471449

Mjaavatn, P. E. (2016). Changes in children's preferences for outdoor activities: A longitudinal study. Leisure/Loisir, 40, 225-244. https://doi.org/10.1080/14927713.2016.1220260

Niklasson, L., \& Sandberg, A. (2010). Children and the outdoor environment. European Early Childhood Education Research Journal, 18, 485-496. https://doi.org/10.1080/135029 3X.2010.525945

Nordbakke, S. (2019). Children's out-of-home leisure activities: Changes during the last decade in Norway. Children's Geographies, 17, 347-360. https://doi.org/10.1080/14733285.2018.1510114

Omelan, A., Huk-Wieliczuk, E., \& Podstawski, R. (2015). Education related to tourism received by Polish tourism and recreation students in childhood and adolescence and its impact on their tourism activity. Polish Journal of Sport and Tourism, 22, 189-194. https://doi.org/10.1515/pjst2015-0026

Pink, S. (2011). What is sensory ethnography [Video File]. Retrieved from http://methods.sagepub.com.proxy.lib.uwaterloo.ca/video/what-is-sensory-ethnography

Poria, Y., \& Timothy, D. J. (2014). Where are the children in tourism research? Annals of Tourism Research, 47, 93-95. https://doi.org/10.1016/j.annals.2014.03.002

Rantala, O., \& Puhakka, R. (2019). Engaging with nature: Nature affords well-being for families and young people in Finland. Children's Geographies. https://doi.org/10.1080/14733285.2019.168 5076

Rautio, P. (2013). Children who carry stones in their pockets: On autotelic material practices in everyday life. Children's Geographies, 11, 394-408. https://doi.org/10.1080/14733285.2013.812278

Schänzel, H., \&Yeoman, I. (2015). Trends in family tourism. Journal of Tourism Futures, 1, 141-147. https://doi.org/10.1108/JTF-12-2014-0006

Skar, M., Gundersen, V., \& O’Brien, L. (2016). How to engage children with nature: Why not just let them play? Children's Geographies 14, 527-540. https://doi.org/10.1080/14733285.2015.1136734

Small, J. (2008). The absence of childhood in tourism studies. Annals of Tourism Research, 35, 772789. https://doi.org/10.1016/j.annals.2008.06.002

Waite, S. (2010). Losing our way? The downward path for outdoor learning for children aged 2-11 years. Journal of Adventure Education \& Outdoor Learning, 10, 111-126. https://doi.org/10.1080/1472 9679.2010 .531087

Wang, S. (2018). Children tourism investigation and analysis in Zhejiang Province, China. Asia Pacific Journal of Multidisciplinary Research, 6(3), 74-81. Retrieved from http:/www.apjmr.com/ wp-content/uploads/2018/07/APJMR-2018.6.3.10a.pdf

Wu, M., Wall, G. , Zu, Y., \& Ying, T. (2019). Chinese children's family tourism experiences. Tourism Management Perspectives, 29, 166-175. https://doi.org/10.1016/j.tmp.2018.11.003 
Zamani, Z. (2016). 'The woods is a more free space for children to be creative; their imagination kind of sparks out there': Exploring young children's cognitive play opportunities in natural, manufactured and mixed outdoor preschool zones. Journal of Adventure Education and Outdoor Learning, 16, 172-189. https://doi.org/10.1080/14729679.2015.1122538

Änggård, E. (2015). How matter comes to matter in children's nature play: Posthumanist approaches and children's geographies. Children's Geographies, 14, 77-90. https://doi.org/10.1080/ 14733285.2015 .1004523 